\section{The Pro-market Housing System and Demographic Change in Taiwan}

Yi-Ling Chen and Herng-Dar Bih

\section{Introduction}

The inadequacies of Taiwan's land tax system and, since the mid-1980s, pro-market housing policies have led to the commoditization of housing in Taiwan (Chen, 2011), resulting in a unique combination of high homeownership rates, high vacancy rates and high housing prices, making it difficult for the housing system to react to social change or to fulfil social needs.

This chapter focuses on the interaction of the three major actors in the Taiwanese housing system - the state, the housing market and the family. The state has played a passive role not only as a supplier but also as a regulator of housing. Government supplied housing contributes only 5.3 per cent of all housing stock, and is primarily built for sale rather than rental (Chen and $\mathrm{Li}, 2011$ ), while only 0.08 per cent of housing stock is public rental housing (Social Housing Advocacy Consortium [SHAC], 2010). The design of the tax system and a lack of transparency in real housing transaction prices lead to speculation. Low housing transaction taxes encourage investment in housing, while low property taxes reduce the cost of maintaining property. As a result, many housing units are left empty as a store of wealth, and vacant housing in Taiwan is remarkable not only for its prevalence but also for its skyrocketing prices.

In this system, it falls to individual families to seek individual solutions and shoulder the primary responsibility to secure shelter. Since the mid1980 s, families have found themselves increasingly exposed to housing 1980s, famitict in ity and faulty housing policy. In response to increasing economic pressures families have also gradually experienced great changes including delayed marriage, a dropping marriage rate and a dropping fertility rate. In 2010 Taiwan's birth rate dropped to 0.9 , among the lowest in the world. These Taiwan's birth rate dre lacking the economic means to accumulate the levels of wealth enjoyed by their ing the economic means to accumilater families later in life. A recently published book, The Falling Generation (Lin et al., 2011), captures the essence of this crisis and lays part of the blame on Taiwan's speculative housing system.

This chapter begins by specifying the role of the state in the housing system, including its means of intervention and its relation to the housing market. Socioeconomic, political and demographic changes since the 1990 s are then analyzed in terms of their effect on the housing system. This is followed by an investigation of the housing affordability crisis beginning in 2005 and the social rental housing movement. Finally, the chapter highlights the high degree of commoditization of Taiwan's housing and suggests that the state should reform the property tax system, be more responsive to demographic changes and place more emphasis on social justice.

\section{Historical context}

State intervention has played a strong role in the economic development of Asia's four little tigers - Singapore, Hong Kong, South Korea and Taiwan but has played very different roles in the development of their respective housing systems, with public housing being considerably less emphasized in Taiwan and South Korea than in Singapore and Hong Kong. Both Taiwan and South Korea embarked on programmes of political democratization beginning in the late 1980s, and their respective governments have responded to the pressure of political competition by expanding social policies (Ramesh, 2003; Wong, 2004). Peng and Wong (2010) argued that Japan, Korea and Taiwan have gradually formed inclusive social insurance which is unlike the individualistic social protection in Hong Kong and Singapore. In recent years, the governments of South Korea and Taiwan have also begun to initiate social housing projects, although a strong social rental housing movement did not begin in Taiwan until 2010.

The development of Taiwan's housing system can be divided into three stages, with the state changing its role and means of intervention over time. These three stages are referred to as laissez-faire, regulation and promotion. In Taiwan, 'public housing' refers to housing provided by the state that primarily is for sale, as opposed to rent.

The laissez-faire housing system from 1949 to the mid-1970s

In 1949, Taiwan experienced a massive influx of war refugees from China's civil war. These refugees concentrated in Taiwan's cities, precipitating a serious housing shortage. The Kuomintang (KMT) government was also new to Taiwan and found itself incapable of managing the initial chaos during which refugees built illegal squatter settlements (Figure 9.1), which themselves expanded as industrialization later attracted rural migrants to the citjes. Public housing was provided only to civil servants working for central government and to very poor people. In the 1950 s, the government began 


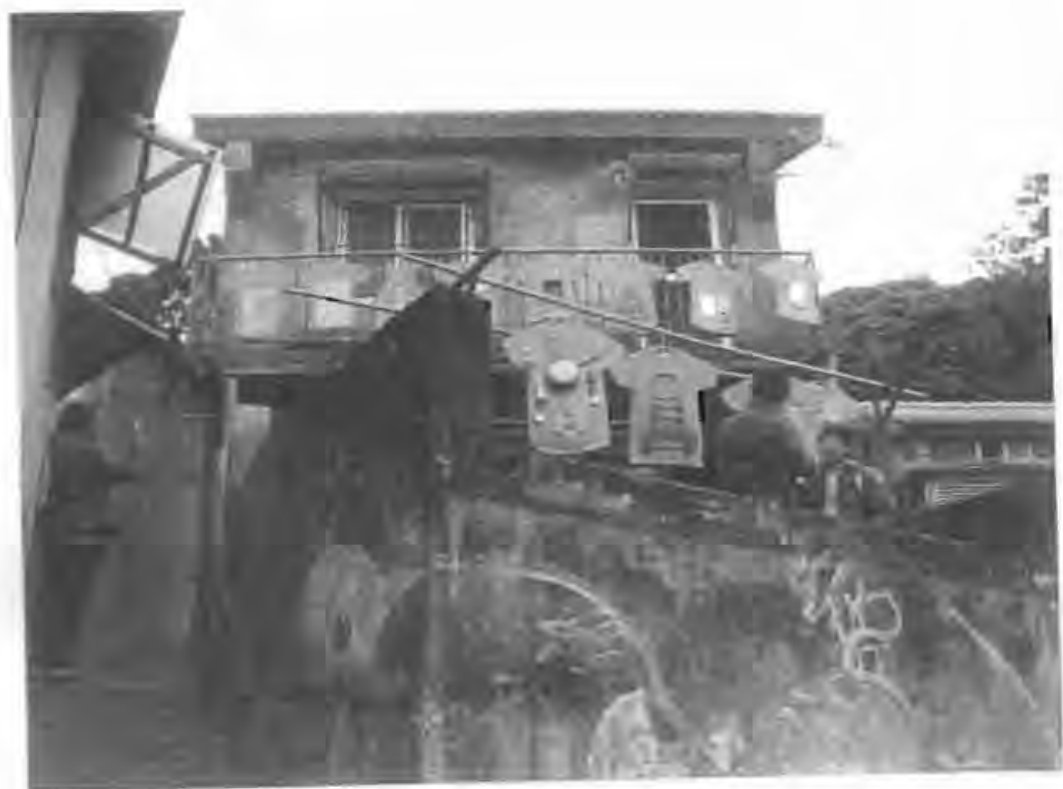

Figure 9.1 Treasure Hill, an illegal settlement in Taipei

Note: Wlith support from many civic organizations, this squatter village was preserved and repurposed as the Taipei Artist Village. Some of the original residents remain, and are pernitted to stay for the rest of their lives, but cannot transfer title. (Yi-Ling Chen)

to emphasize economic development, taking control of financial institutions and directing investment towards key industries. However, housing tions and directing inve state conwas not a high priority for financial policy so that, although the state controlled the banks, there was no mechanism for providing loans to either private property developers or homebuyers.

In the 1960s, the economic agenda emphasized the development of labour-intensive light industry, shifting from an import-substitutive towards ath economic growth averaging around an export-led economic strategy. With economic growth averaging around 9 per cent through the 1960 s, Taiwan rose to become a newly industrialized country in the system of the new international division of labour (Hsu, country in the system of the government to 2011). Rapid urban expansion during this time forced the government to begin improving urban infrastructure, with a small amount of public hous ing constructed for households affected by urban construction (Figure 9.2). ing constructed for households affected by urban construction (he housing market and, most importantly, the establishment of private construction market and companies (Tseng, 1994: 91-96). Without any institutional intervention an informal prefinancial support from the state, private developers created an informal pre-

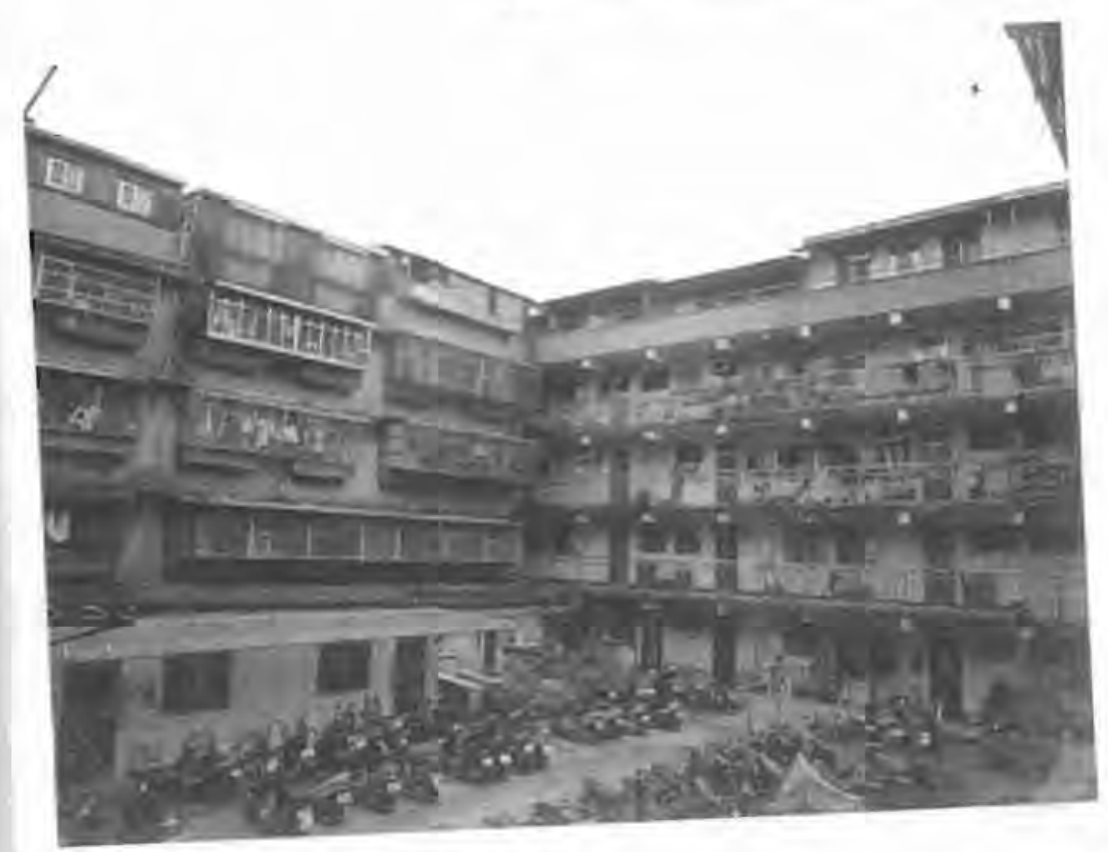

Figure 9.2 Fu-Yuan District Public Housing

Dach unit is only $363 \mathrm{~mm}^{3}$ Note: Built around

(Sheau-Wen Tarng)

位 scheme consumers paid a proportion of the housing completed, thus providing tion, and paid the balance when the project was completed, thus Wu, 2004). However, buying pre-sale housing was highly risky because of a lack of legal its development was a manifestation of the absence of sta intervention ( $\mathrm{Li}, 1998$ )

, the KMT goveroment intervened minimally in soclal Before the mid-1970s, the KMT government intervened minimall. Demand for welfare, adopting a laissez-faire position in the housing market. Deut much of housing prompted the formation of a private housing market, but much of this market was informal and characterized by construction without pestablish

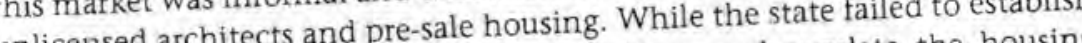
unlicensed architects and presulate the housing formal financial and legal systems to faciltate and the housing shortage market, the informal housing sector helped mitigate the housing shortage market, the informal ho social reproduction, for example through the use of and reduce the cost of social reproduction, for squatter settlements. However pre-sale financing and the development of squatter settlem consumers and the key drawbacks included the lack of legal protection for consumers and thily fact that, in the absence of consumer loans and public assistance, each family had to put up the purchase price in cash, whi

borrowing through their kinship network. 
The era of state promises: The mid-1970s to the mid-1980s

The mid-1970s marked a major change in social policy as well as in housing policy. The KMT government enacted the 'Public Housing Act' in 1975 and incorporated the 'Six-year Housing Construction Programme' (1976-1981) into the national economic plan, aiming to provide 100,000 units of public housing (Figure 9.3). The driving force for this large-scale housing project came not from labour or social movements, but was rather in response to two oil crises and diplomatic isolation (Mi, 1988, p. 113). In 1971 Taiwan lost her seat in the United Nations to China and in 1979 the United States terminated diplomatic relations, leaving the KMT government without a valid claim to sovereignty over Mainland China. Meanwhile, domestic democratic movements emerged to question the legitimacy of the authoritarian state. The KMT state faced a severe confidence crisis, and the situation worsened when the two oil shocks of the 1970s hit Taiwan's import-based, energy-dependent economy. The resulting rapid inflation, combined with rapid GDP growth and an increase in the money supply contributed to a housing boom. Upper-income families, seeking to preserve their wealth in real estate, drove up housing prices so quickly that middle-income people found themselves even less able to afford housing. Introducing the public housing programme therefore served to help the government to restore

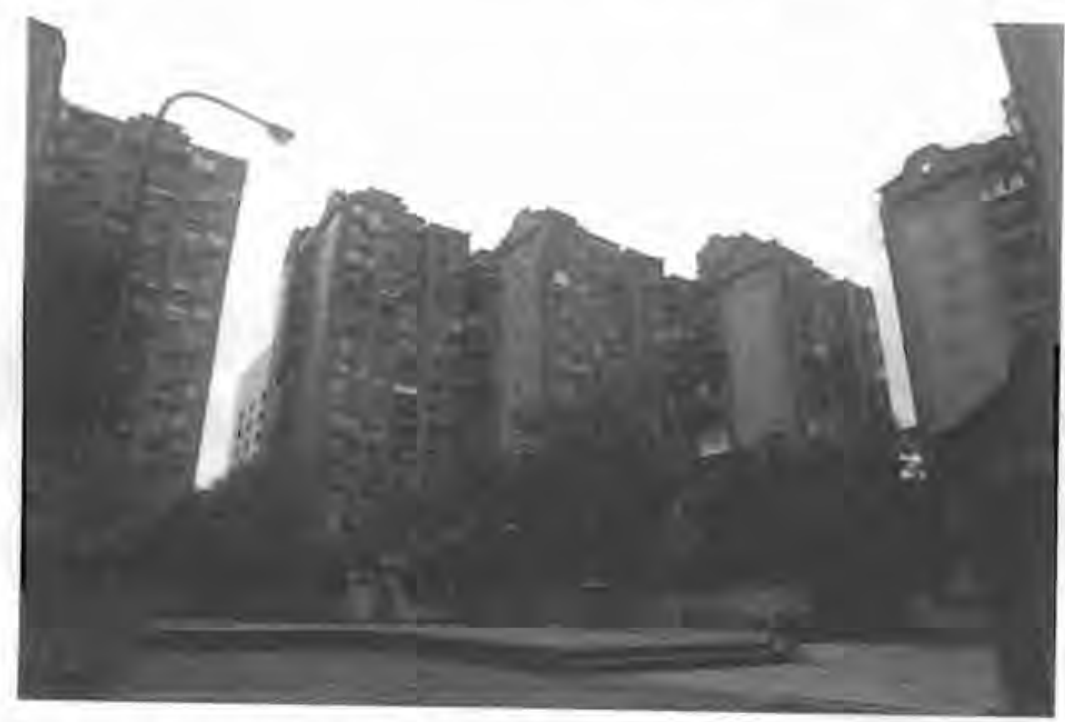

Figure 9.3 Da-An District Public Housing, completed in 1985 under the Six-year Housing Construction Programme Note: The newer units are larger with two to three bedrooms a piece and more public space.
(Herng-Dar Bih) political legitimacy (Mi, 1988). These public construction projects also served to prop up domestic construction companies, and thus știmulate the economy, in imitation of Singapore.

However, Taiwan experienced considerable difficulty in implementing the Singaporean model. Urban land in Taiwan was mostly in private hands, making the cost of land acquisition prohibitive, especially given that Taiwan had no source of funding equivalent to Singapore's Central Provident Fund. Taiwan's housing authority had planned to build low-cost housing for sale to low-income families, but the high cost of land boosted the final price of the flats out of the reach of the target consumers. Rather than further subsidize the price, the government relaxed the income ceiling. In the end, many of the flats built for low-income families were purchased by middle and upper-income consumers (Housing Department of Taipei City Government, 1987). Yet, the purchase price was still lower than the market price, attracting speculators who later resold the flats at a profit.

Taiwan's public housing, then, was almost entirely built for sale, not rent. In this sense, these large-scale housing projects in the 1970 s established lasting trends in housing policy: housing was treated as a commodity, and not built for those who most needed access to public assistance.

During the economic stagnation in the 1970s, the housing project boosted the construction industry and created some jobs. However, the project failed to reduce the cost of social reproduction or labour costs, and public housing had little role in stimulating economic growth. Rather, the national economic plan implemented another major project: Ten Great Constructions, including the construction of Taiwan's first highway, an overhaul of the railway system, harbour expansion and the construction of petrochemical and steel facilities, which helped transform Taiwan's industrial base towards heavy industry. The economy soon recovered and achieved a sustainable footing.

The massive housing construction programme, however, did mark a change in the government's attitude towards the housing market, with action being taken to control the housing market by direct involvement in housing con ${ }^{\text {* }}$ struction, aiming to increase the housing supply and lower housing prices. In addition, the government also began to control funding for house purchases and to adjust taxes related to housing sales. The purpose of these actions was to put a stop to unregulated housing development and speculation. Whereas authoritarian rule could impose these measures with little opposition and speculation soon cooled down, they were only temporary since there was actually no intention of establishing comprehensive regulations for the housing market.

The nature of state intervention in housing from the 1970s to the mid1980 s, then, was regulatory and Keynesian. The government began to take action to regulate the housing market but did not intend to establish longterm market regulations. Although housing policy was incorporated into 
the national economic plan, its contribution to economic development was limited, and the social welfare aspects of housing were largely ignored.

\section{Liberalization from the mid-1980s}

In the early 1980 s, the United States responded to its surging trade deficits by instituting protectionist trade policies and pressed Taiwan to open its markets to international trade (Mi, 1988). In addition, under US pressure Taiwan's currency appreciated by about 40 per cent against the US dollar between 1986 and 1989 (Chang, 1995), but with foreign exchange restrictions loosened in 1987 foreign capital surged into Taiwan's financial markets for investment in Taiwanese dollars (Hsiao and Liu, 1993). With a savings rate of about 30 per cent of GNP through the 1980s, Taiwan had a large supply of idle money to further fuel property speculation. The government responded to calls for economic liberalization from the US and large domestic enterprises by privatizing state-owned enterprises, abolishing controls on interest rates and exchange rates, and reducing tariffs. Financial markets were de-regulated in the mid-1980s and interest rates began to drop ( $\mathrm{Li}$, 1998). Investors could get more funding from banks and depositors were seeking better retums than those available from banks, so the decrease of interest rates intensified housing speculation. The government also moved from controlling the housing market to establishing regulations to stimulate it. This included such measures as encouraging banks to provide mortgages and facilitating the establishment of real estate management firms to intervene in housing investment, consumption and finance to ameliorate the problems associated with pre-sale housing (Mi, 1988).

1986 also saw the establishment of Taiwan's first formal opposition party, the Democratic Progressive Party (DPP). The forces of economic liberalization and political democratization gradually challenged the authoritarian KMT state and its top-down relationship with the market. The government lost control of the housing market and prices more than tripled in the six years from 1986 to 1992 (Chang, 1995). Rampant land speculation in the late-1980s, however, provoked Taiwan's first popular housing movement, which pushed the government to increase the construction of public housing and improve financial controls on loans to private developers. These actions successfully slowed the rise of housing prices.

Economic liberalization again became popular in the 1990 s as Taiwan applied to join the World Trade Organization. Taiwan applied for membership in 1992 before the WTO was formally established, and finally became a member in 2002. Public policies in the 1990s were more explicitly aimed at economic liberalization and deregulation to promote Taiwan's WTO bid. In housing, the KMT government sought ways to balance the demands of voters and the goal of liberalization, partially through the development of housing mortgage programmes. In 1990, the government established a number of mortgage subsidy programmes for different groups of people.
Although state employees and military personnel still enjoyed the greatest housing support, benefits were extended to other groups, including workers, aboriginals and first time home buyers. The government began to play an active role in channelling money from banks to the housing market (Construction and Planning Agency [CPA], 2006). Another significant change was an increase in the proportion of privately constructed public housing, built for sale rather than rent, which in the 1990 s equalled that constructed by state agencies (CPA, 2007). Qualifications and subsidies for residents in privately constructed public housing were similar to those used in government-built public housing built by the government.

Responding to popular pressure, mortgage programmes were further boosted in 2000 under the DPP presidential administration which created a mortgage programme specifically targeting people between 20 and 40 years old. Thus, since the early 2000 s, with the goal of promoting the housing market, mortgage programmes have become the key element in housing policy. In 2008, the KMT regained power and contimued this policy.

The pro-market transformation of the housing system since the 1980 s was accompanied by the rise of Taiwan's capitalist class. Following economic liberalization in 1986, business groups began to play an increasingly vital part in Taiwan's economy and have increasingly consolidated their position. The market gradually came under the control of a small number of large business groups (Chu and Hung, 2002), many of which had interests in real estate. In 2010 , Forbes counted 18 Taiwanese billionaires, eight of whom were heavily involved in real estate (China Times, 2010b). Since the 1980s, the KMT had drawn legitimacy from the support of these real estate developers. Following democratization, the relationship between the state and the developers grew even closer, as the state needed to rely even more on their support. The developers themselves participated in elections and promoted their own representatives to stand in the legislature. This resulted in the focus of housing policy shifting towards increasing the proportion of consumers in the housing market through the extension of mortgages, and indeed with subsidized mortgages becoming the primary focus of housing policy.

Alongside these developments, only very limited financial assistance has been provided to renters. In 2000, under the KMT, the Ministry of Finance implemented an income tax deduction of up to NT\$120,000, while in 2007 the DPP administration provided low-income renters with a monthly subsidy of NT $\$ 3,000$, benefitting at least 120,000 households annually. However, compared to market rental rates, the subsidies are quite small, and renters using these subsidies are treated poorly by the housing market. Thus, the housing market is still seen as the best solution for both mortgages and rent subsidies, but it is questionable whether market mechanisms can solve the problem of low-income housing.

In contrast to the neo-liberal reforms in many European and North American countries, Taiwan's state intervention in the housing market 
increased in the 1990s, but the logic of housing intervention gradually shifted towards market mechanisms and neo-liberal principles as the state strategically applied neo-liberal reforms (Chen and $\mathrm{Li}, 2011$ ). While state intervention in housing had been minimal previously, following 1990 the state began to increasingly intervene, moving from the construction of public housing to encouraging homeownership through the liberalization of mortgage policies. The increased availability of mortgages and subsidized interest rates allowed more consumers to enter the private housing market, boosting the real estate and financial markets, while public rental housing remained a marginal component of the overall housing system.

Socioeconomic, political and demographic changes since the $1990 \mathrm{~s}$

With these attempts to promote homeownerslip, the housing market has faced a growing schism. Economic restructuring increased social inequallty, while housing policies have favoured the continued growth of the housing market and prevented the decline of house prices. Taiwan's wealthy have taken advantage of these conditions to invest their wealth in real estate, while middle- and low-income families increasingly have struggled to afford housing in the face of eroding incomes and rising housing prices. Since the 1990 s, socioeconomic, political and demographic changes have exerted a strong impact on housing and future housing policies, but the high degree of commoditization of housing prevents the government from effectively addressing these issues. Dependence on the private housing market to provide solutions also signals that the government is not inclined to control house prices or assist those who have little chance of achieving homeownership.

Economic restructuring and social inequality

Following the collapse of Taiwan's asset bubble in the late 1980s, economic growth began to slow down and fell below 10 per cent (see Figure 9.4). Beginning in the 1980s, Taiwan also faced increasing competition for foreign investment from China and Southeast Asian countries. The rapid appreciation of the Taiwan dollar in the late 1980s increased the cost of labour, eroding the competitiveness of labour-intensive industries, which gradually moved out of Taiwan, initially to countries in South East Asia but, after 1987, increasingly to Mainland China (Hsu, 2011). Taiwanese direct capital investment in China increased rapidly. In 2005, China surpassed the US and Japan as Taiwan's largest trade partner (Wu, 2010). In a new international division of labour, Taiwan transferred many of its industrial production lines to China, beginning with low-skilled, labour-intensive industries in the 1980 s and then followed by high-skilled, high-tech industries in the late 1990 s (Hsu, 2011). Although cross-strait investments have enhanced the competitive advantage of Taiwanese firms, they also significantly reduced job opportunities and workers' conditions in Taiwan.

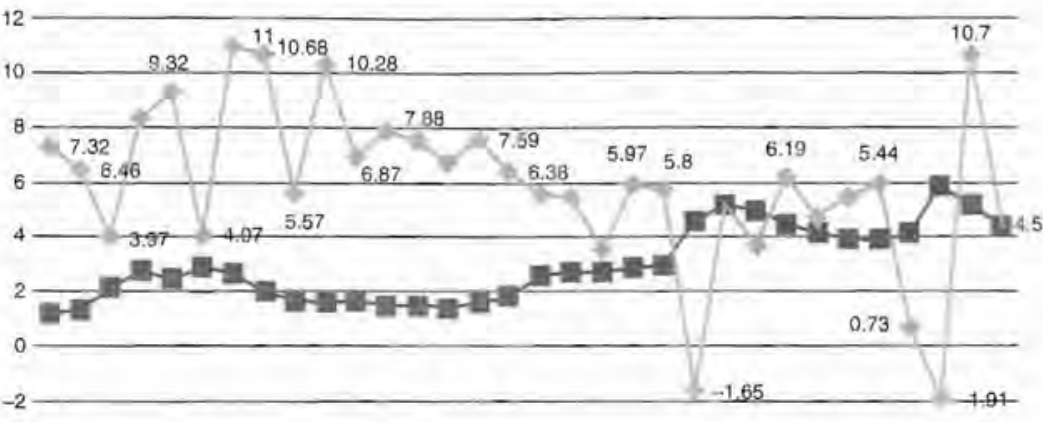

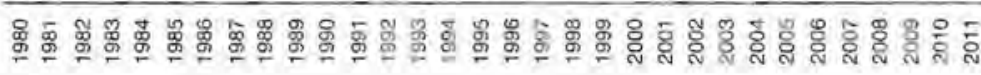

Figure 9.4 GDP growth rate and unemployment rate, 1987-2011 Source: DGBAS (2011a),

In 2010 , overseas production by Taiwanese manufacturers reached 50 per cent of Taiwan's total manufacturing output (Li, 2010). Taiwan's employ. ment structure has gradually transformed from manufacturing to setvices, with employment in the service sector first exceeding the industrial labour force in 1987. Labour-intensive manufacturing had previously helped balance regional development in Taiwan because the distribution of factories was relatively uniform throughout the island. However, the decline of both the industrial and agricultural sectors accelerated the process of urbanization. Over the past decade, Taiwan's population has increasingly concentrated in the island's three major metropolitan areas, especially in the northern region where most of the high-tech companies are located (DGBAS, 2011b).

Since the 1990s, structural unemployment has gradually increased, with overall unemployment reaching a record 5.9 per cent in 2009 (Figure 9.4). Working conditions have also deteriorated as the number of non-regular workers has increased. From 2001 to 2009, the number of part-time workers tripled (Li, 2010), with these workers earning on average 50 per cent less than their full time counterparts (Lin et al., 2011). Following the 1990s, workers' conditions were characterized by long working hours, high consumer prices, and low wages (Lin et al., 2011).

The younger generation has been most affected by the economic restructuring. By 2009, the long-term unemployment rate reached 34.2 per cent among people below 30 years old, of which 30 per cent had a university education or above ( $\mathrm{Li}, 2010)$. In addition, the income gap has widened. In 1998 , the average income for those with the top 5 per cent of incomes was 
33 times greater than for those with the lowest 5 per cent, but this increased to 65 times in 2008, 75 in 2009, and 93 in 2010. The 2008 financial crisis hit the lowest 5 per cent group hardest because their incomes dropped more dramatically than other groups, thus accelerating the increase in the income gap after 2008 (Liberty Times, 2011 and 2012).

\section{Demographic transformations}

Economic restructuring has also slowed the process of family formation. From 1956 to 2010, the percentage of adults aged 25 to 34 who had never married rose from 11.4 per cent to 56.7 per cent (Table 9.1). Families are also smaller, and while nuclear families are still the dominant household type, their numbers are falling as the number of one person households increase. In 2010, nuclear families accounted for $\$ 4.5$ per cent of all households, as opposed to 22 per cent for one person households (Table 9.1).

The rising status of women in Taiwan has also contributed to family change. Since the start of economic restructuring, women have played a growing role in the labour market, with female labour participation increasing from 32.3 per cent in 1980 to 49.9 per cent in 2010 , and that of men decreasing from 77.1 per cent to 66.5 per cent over the same period (Table 9.1). The wage gap between men and women has also gradually closed, with the ratio of average salaries for women to men rising from 69 per cent in 1980 to 80.1 per cent in 2010 (Table 9.1). In 1990, women were the primary income earner in 18.2 per cent of households; by 2010 , this had increased to 33 per cent (Table 9.1).

Women's improved economic status has also given them greater autonomy in decisions regarding marriage and family life. From 1999 to 2009, the proportion of women aged 15 and above who were married declined from 57.2 per cent to 51.7 per cent, while the proportion of divorced women rose from 4.2 to 7.2 per cent, and that for women who had never married also rose slightly from 30.3 to 31.6 per cent (DGBAS, 2011c). The increase of nevermarried women was especially pronounced among the younger generation. In 2010, 95.9 per cent of women aged 15-24 were unmarried, as opposed to 47.8 per cent for women aged $25-34$, and 14.7 per cent aged 35-44. Compared with 2000 , the percentage point increases were $6.2,14.6$ and 5.7, respectively (Table 9.2). The ratios of men who were never married, or were divorced or separated all increased significantly over the period 2000-2009 (Table 9.2).

Although an increasing number of households are headed by women, these households are more likely to be poor, with an average income of only 81.3 per cent of those headed by men in 2009 (DGBAS, 2011c). Among the low-income households that receive social welfare programmes, the ratio of female-headed households reached to 45.2 per cent in 2008 (Department of Statistics, Ministry of Interior, 2008).

The most striking effect of the economic restructuring has been the dramatic fall in Taiwan's birth rate, with births per 1,000 women aged between
Table 9.1 Gender, marriage, family and housing status in Taiwan, 1956-2010

$\begin{array}{llllllll}1956 & 1966 & 1970 & 1980 & 1990 & 2000 & 2010\end{array}$

Women's status

Fermale labour

participation rate $(\%)$ *

Male labour participation

rate $(\%)$ *

Female to male average

wage (\%) *

Total fertility rate

Female householders (\%)

Marital status

Age 25-34 population,

never married (\%)

Age 15 and older population, $\quad 27.6 \% \quad 33.2 \% \quad 35.2 \% \quad 35.7 \% \quad 34.2 \% \quad 33.5 \% \quad 33 \%$ never married $(\%)$

Age 15 and older population, $1 \% \quad 1.6 \% \quad 1.8 \% \quad 1.3 \% \quad 2 \% \quad 2.9 \% \quad 5.5 \%$ divorced or separated (\%)

Age 15 and older

population, widowed $(\%)$

Family starus

$\begin{array}{lllllllll}\text { Average persons in household } & 5.7 & 5.7 & 5.5 & 4.8 & 4 & 3.3 & 3\end{array}$

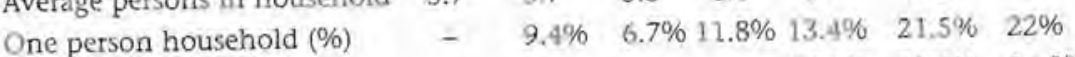

Nuclear families (\%)

Single parent families (\%)

Number of elderly living

alone (age $65+$ )

Housing status

Homeownership rate (\%)

Vacant housing rate (\%) $\begin{array}{lllllll}8.4 \% & 6.2 \% & 5.7 \% & 4.7 \% & 4.8 \% & 5.3 \% & 5.4 \%\end{array}$

\begin{tabular}{|c|c|c|c|c|c|}
\hline - & - & - & $39.3 \% 44.5 \%$ & $46.0 \%$ & $49.9 \%$ \\
\hline & - & - & $77.1 \% 74 \%$ & $69.4 \%$ & $66.5 \%$ \\
\hline & & - & $69.0 \% 67 \%$ & $74.1 \%$ & $80.1 \%$ \\
\hline
\end{tabular}

$\begin{array}{rrrrrrr}6.5 & 4.8 & 4 & 2.5 & 1.8 & 1.7 & 0.9\end{array}$

$63.6 \%-55.1 \% \quad 54.5 \%$

- $\quad$ - $\quad 5.8 \% \quad 5.8 \% \quad 7.6 \%$

- $\quad$ - $\quad 167,827299,328350,456$
$11.4 \% \quad 15 \% \quad 14.3 \% \quad 20.9 \% \quad 31.6 \% \quad 42.3 \% \quad 56.7 \%$

Note: * DGBAS, 2012; * Chang, 2011, p. 283; *** Depariment of Household Registration, winibity of Interior, 2012

Sounce: DGBAS $(1980,1990,2000,2010)$.

15 and 49 dropping from 6.5 in 1956 to 0.9 in 2010 (Table 9.1). The rapid decline in the fertility rate has greatly changed the composition of the population, contributing to its rapid ageing: the proportion of the population 65 or older rose from 2.5 per cent in 1966 to 10.7 per cent in 2010, while the population aged 15 or under shrunk from 44.2 per cent to 15.8 per cent (Figure 9.5).

The sudden drop in the fertility rate could be a manifestation of a 'fertility strike' against the lack of public support for child care (Lin et al, 2011). The 
Table 9.2 Gender, marital status and age, 2000 and 2010

\begin{tabular}{|c|c|c|c|c|}
\hline \multirow[b]{2}{*}{ Gender/age } & \multicolumn{2}{|c|}{2000} & \multicolumn{2}{|c|}{$20 \div 0$} \\
\hline & $\begin{array}{l}\text { never } \\
\text { married (\%) }\end{array}$ & $\begin{array}{l}\text { divorced or } \\
\text { separated }(\%)\end{array}$ & $\begin{array}{l}\text { never } \\
\text { married (\%) }\end{array}$ & $\begin{array}{l}\text { divorced or } \\
\text { separated }(\%)\end{array}$ \\
\hline \multicolumn{5}{|l|}{ Men } \\
\hline $15-24$ & 96.7 & 0.2 & 98.6 & 0.1 \\
\hline $25-34$ & 51.3 & 2.0 & 65.8 & 2.9 \\
\hline $35-44$ & 14.5 & 4.6 & 20.2 & 8.2 \\
\hline $45-54$ & 5.7 & 5.2 & 8.0 & 8.9 \\
\hline $55-64$ & 3.4 & 3.3 & 3.5 & 7.2 \\
\hline $65+$ & 7.2 & 2.4 & 3.4 & 3.9 \\
\hline \multicolumn{5}{|l|}{ Women } \\
\hline $15-24$ & 89.7 & 0.4 & 95.9 & 0.3 \\
\hline $25-34$ & 33.2 & 2.6 & 47.8 & 4.0 \\
\hline $35-44$ & 9.0 & 5.5 & 14.7 & 3.9 \\
\hline $45-54$ & 4.2 & 5.4 & 6.5 & $10 !$ \\
\hline $55-64$ & 1.5 & 2.7 & 3.6 & 7.5 \\
\hline $65+$ & 1.0 & 1.3 & 1.9 & 2.9 \\
\hline
\end{tabular}

Source: DGBAS (2011b).

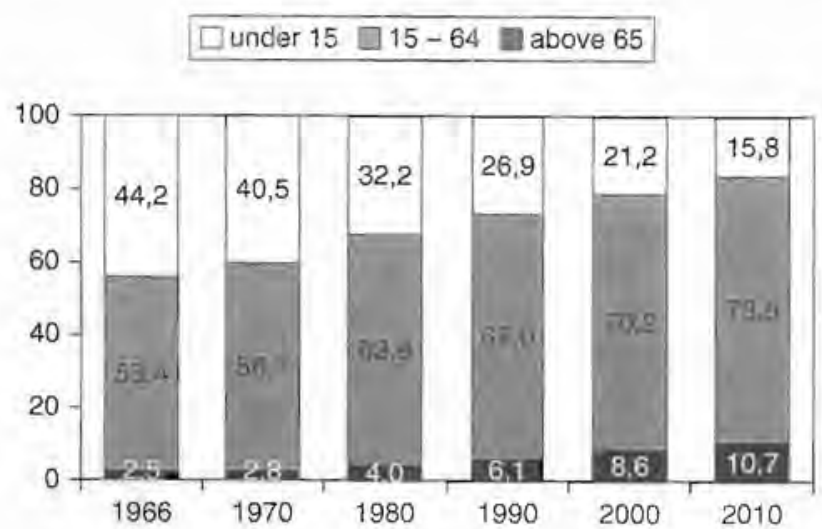

Figure 9.5 Age distribution, 1966-2010

Source; DGBAS (2011b, p. 11)

elevation of women's status has weakened Taiwan's dominant patriarchy, though its influence persists. Women continue to be largely responsible for housework. As of 2004, 75 per cent of women over the age of 15 reported regularly handling housework duties and providing primary care for family members and their children, as opposed to 31.3 per cent for men (DGBAS, 2007). Social welfare policies are based on a 'familial ideology' that holds the family primarily responsible for providing for the welfare of its members $(\mathrm{Hu}$, 1995. Fu, 2010) In 2010,88.3 per cent of children under four did not attend $1995, \mathrm{Fu}, 2010$. In $2010,88.3$ pere centres are run by the day care (DGBAS, 2011b). Only 7.1 per cent of day care centres are the day care government (Xie, 2010). While some subsidies are provided for the day care expenses of the lower income families, child care policy is large

private initiatives and market mechanisms (Lin et al., 2011).

Families are also the primary carers for older people in Taiwan. In 2010 52.2 per cent of people over 65 years old lived with their children (DGBAS, $2011 \mathrm{~b})$. However, the number of people, aged 65 or older who were living alone more than doubled between 1990 and 2010 (Table 9.1). About 16.8 per cent of older people require assistance in their everyday lives. Among these, 3.9 per cent live in institutions, 16.6 per cent hired a foreignor domestic helper, 62.8 per cent relied on their tamilies and the remaining 12.1 per cent lived without any assistance (Department of Statistics, Ministry of Interior, 2011).

Under the 'familial ideology' approach, direct state intervention in the care of older people is very limited. The social welfare policies of Taiwan's government offer little support for families, however. Rather than provide direct aid or services, the government prefers to subsidize the purchase of services from the private market, and the market-led housing system leaves families primarily responsible for securing their own housing. However, with the increasing prevalence of one-person and single-parent households, family formation is more unstable than before, but housing policies continue to favour nuclear families, with unmarried people unable to benfit from housing policy until they turn 40 years old. Housing policy also implicitly discriminates against gay and lesbian couples because the state does not recognize gay marriages. The deceleration of family formation is a signal that the family unit is no longer able to assume such a heavy burden for social reproduction, especially in times of economic restructuring and evolving gender relations.

Set against this, policy makers seem to favour members of the younger generation. Since 2000, householders between 20 and 40 can apply for government-backed low-interest mortgages. However, housing prices have continued to rise quickly, and deteriorating working conditions have reduced incomes in this age group, creating a widespread housing crisis among this group.

\section{Recent development}

Housing affordability crises since 2005

Given the volatility of the economy, Taiwan's housing boom, beginning in 2005 , came as something of a surprise. Pre-sale housing prices increased 
74 per cent from 2005 to 2010 and show no signs of slowing down (Flgure 9.6). The major cause was the massive return of Taiwanese overseas capital due to the uncertainty of global financial markets, compounded by a reduction in inheritance tax: estate and gift tax was revised in 2008, reducing inheritance tax rate from 50 to 10 per cent (China Times, 2010a). Low interest rates on mortgages (below 2 per cent since February 2009) have also contributed (Central Bank of Taiwan, 2011). On 29 June 2010, Taiwan and China signed a preferential trade agrement (the Economic Cooperation Ir signed Agreement, or ECFA), and anticjpation of futtre Cooperation Framework increasing capital from and office buildings. Taiwan still imulated investment in residential housing people from the People's Republic of Chingent residency restrictions on people the absolute number of housing sales to mainland Chinese. However, many real estate investments are conducted through transnational corporations, which may include Chinese shareholders, making the real impact of Chinese capital in Taiwan's real estate market difficult to ascertain. However, the influence of this capital influx has been publicly exaggerated, fuelling speculation as local property investors anticipate future buying by Chinese nationals.

The housing bubble has significantly worsened housing affordability. Real housing transaction prices were not transparent before August 2012, and the primary sources of housing price information were academic surveys and data released by real estate companies. Table 9.3 shows survey data on recent homebuyers in Taipet and six major Taiwanese cities. These homebuyers were able to make a down payment of on average around 30 per cent of the total price. However, even for people of relatively significant means, in 2011 the average house price in Taipei City was the equivalent of 14.3 times

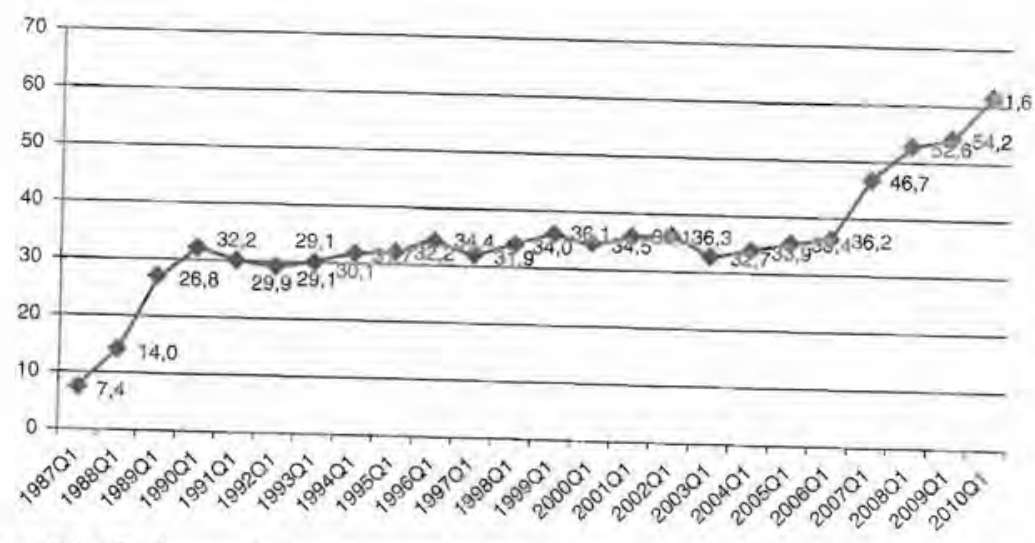

Figure 9.6 Real pre-sale house prices in Taipei City

Note: *Unit: NTS 10,000 per ping $\left(3,3058 \mathrm{~m}^{2}\right)$. Prices adjusted for inflation. Source: Chang, Chen and Yang (2010).
Table 9.3 House prices and affordability in Taipei and six major Taiwanese Cities, 2004-2011

\begin{tabular}{|c|c|c|c|c|c|c|}
\hline \multirow[b]{2}{*}{ Year/quarter } & \multicolumn{3}{|c|}{ Taipei City } & \multicolumn{3}{|c|}{ Six major Taiwanese Cities } \\
\hline & $\begin{array}{l}\text { Average } \\
\text { house price } \\
\text { (NT10,000/ } \\
\text { ping*) }\end{array}$ & $\begin{array}{l}\text { House } \\
\text { price to } \\
\text { annual } \\
\text { income }\end{array}$ & $\begin{array}{l}\text { Mortgage } \\
\text { payment } \\
\text { to incorne } \\
\text { monthly }\end{array}$ & $\begin{array}{l}\text { Average } \\
\text { house price } \\
\text { (NT10,000/ } \\
\text { ping) }\end{array}$ & $\begin{array}{l}\text { House } \\
\text { price to } \\
\text { annual } \\
\text { income }\end{array}$ & $\begin{array}{l}\text { Mortgage } \\
\text { payment } \\
\text { to income } \\
\text { monthly }\end{array}$ \\
\hline 2004Q4 & 24.9 & 7.4 & $30.6 \%$ & 11.8 & 6 & $27.1 \%$ \\
\hline $2005 Q 4$ & 26.7 & 8.9 & $31.9 \%$ & 15.5 & 6.9 & $28.4 \%$ \\
\hline $2006 Q 4$ & 30.7 & 8.8 & $39.4 \%$ & 16.7 & 6.6 & $30.9 \%$ \\
\hline 2007Q4 & 34.4 & 8.6 & $36.5 \%$ & 17.8 & 7.1 & $30.8 \%$ \\
\hline $2008 Q 4$ & 31.3 & 10.2 & $43 \%$ & 17.5 & 7.1 & $29.6 \%$ \\
\hline 2009HY2 & 33.9 & 9.1 & $36.1 \%$ & 18.8 & 7.1 & $28.2 \%$ \\
\hline $2010 Q 4$ & 49 & 14.3 & $56.2 \%$ & 22.8 & 8.9 & $36 \%$ \\
\hline $2011 Q 3$ & 62.2 & 14.3 & $46.6 \%$ & 24.7 & 9.2 & $34.6 \%$ \\
\hline
\end{tabular}

Note: ${ }^{-1}$ ping $=3.3058 \mathrm{~m}^{2}$

Source IPPI (2004-2011).

annual income, while the multiple for the average of the six cities was 9.2 . In Taipei, new homebuyers paid 46.6 per cent of their monthly household income towards their mortgage, compared to an average of 34.6 per cent for the six major cities. At these Ievels, house prices were considered unaffordable for these recent homebuyers, let alone for people who were still trying to save money for the down payment. This implies that homeowsership has been further restricted to higher income groups in recent years.

Even given high house prices, simultaneous high rates of homeownership and vacancies present an apparent contradiction. Taiwan's rate of homeownership reached 83.9 per cent in 2010 , against a vacancy rate of 19.3 per cent (Table 9.1). In Taipei City, Taiwan's most expensive area, homeownership was lower at 75.2 per cent with a vacancy rate of 13.4 per cent. How can these simultaneously high rates of homeownership, vacancies and housing prices be interpreted? It is widely believed that this is a cultural phenomenon, specifically the premium that Chinese people have traditionally placed on land as an asset that holds its value (Xiong, 2012). However, structural factors also play a role by creating a housing system that is highly commoditized, seriously neglects social justice and promotes speculation.

The lack of a secure social welfare system means that people must seek individual solutions to their housing problems. Also, the housing system provides little in the way of protection for non-homeowners: there is no social housing system to speak of, and the state barely regulates the rental housing market; rental housing practices do not provide adequate 
protections for either landlords or tenants, but tenants are especially vulnerable. Despite the cost, owning a home is still often the best way for families to ensure stable and secure housing conditions.

Housing has also provided investors with a useful tool for both preserving and expanding wealth. A 2011 survey of new home buyers showed that 15.8 per cent of purchases were primarily made for investment, and of these, 41.8 per cent of purchases were not made primarily to rent, but to resell at a profit (IPPI, 2011). The transaction tax is calculated according to a property's assessed value (Announced Present Value, APV), which, as calculated by the government, is far below the real market price, so that the actual transaction tax incurred by investors and speculators is low. Given this, many homeowners prefer to leave their investment properties vacant, selling when prices are good or when they need money. In this way, high vacancy rates persist despite the high house prices.

Housing is also seen as a good investment because, in living memory, abrupt drops in housing prices are largely unknown. Figure 9.6 shows real pre-sale housing prices in Taipei City from 1987 to 2010. Two big surges can be seen since the late 1980s. Between these two surges, housing prices stayed relatively stable despite slowing economic growth. Pre-sale housing includes only newly constructed housing, so the price is above the average. Since the mid-1990s, Taiwan has experience four sharp drops of economic growth: the Asian financial crisis in 1997, the 9/11 incident in 2001, the SARs outbreak in 2003, and the Giobal Financial Crisis in 2008. Throughout this time, the unemployment rate has risen steadily. Taiwan was not as badly hit by the 1997 Asian financial crisis as other Asian countries because the domestic financial system was relatively less open at the time. The pro-market housing policies enacted since 1990 have played an important role in sustaining the housing market. During these four economic slumps, the government provided additional funds for low-interest mortgages and in 2001 the land value incremental tax rate was reduced by half.

\section{The social rental housing movement since 2010}

Rising housing prices in the face of economic recession have triggered mounting social unrest, and media critics have increasingly criticized housing prices. In 2010, a non-profit organization called the 'Social Housing Advocacy Consortium' was founded in order to advocate for affordable housing, and serious public debates have begun to raise the issue of social rental housing. The movement is still advancing and has provoked policy debates among interest groups. The new discourse on social housing seems to be creating possibilities for disadvantaged people who have little chance of becoming homeowners (Chen, 2011).

In 2011, partially in response to the housing movement, the government enacted a luxury tax (Chen, 2011), and the Taipei City Government re-designated newly-built transitional housing as a social housing project. The 119 housing units had originally been built for the relocation of families displaced by public construction, but were redirected towards young householders aged between 20 and 40 and with household incomes lower than the average in Taipei. Several disadvantaged groups unsuccessfully petitoned the Taipei City Government to allocate 30 per cent of these units for the elderly, single-parent families, people with disabilities and poor people (SHAC, 2011a).

Five future projects in greater Taipei will provide 1,661 new units of social rental housing, but protests by surrounding residents and budget limitations rental housing, but pes (cnYES.com, 2012). Currently, central government plans to offer incentives to private developers to build and operate social plans to offer in on pulic land for a fixed period of time. This method is referred to as build-operation-transfer (BOT), and has been widely used by the government to implement construction projects since the 1990 s. The target residents for social housing are people between 20 and 40 years old, arguably because they tend to be politically engaged and are seen as a powerful voting bloc. However, to date, the overall number of social housing units is very small with very limited social welfare impact.

Central government has recently proposed building an affordable housng project in a newly developed area on the outskirts of metropolltan Taipeir Nearly all the housing ( 3,960 units) will be offered for sale with only 199 units for renting. Four construction companies will participate . The government will be responsible for sales. Thus, this housing project is to previous ones in that it focuses on sale, rather than rental, and is not targeted at low-income families that most require housing assistance. The qualification for purchase is very loose, requiring purchasers to have household incomes below the average for Taipei City, but, given that Taipei is Taiwan's richest city, this sets the bat rather high. Critics say that this is is Taiwan's riches clottery public housing' because many purchases will be another instance or lottery public housing because (China Times, 2011) able to sell the properties for a profit after fure yearial objectives adequately,

The recent Housing Act also fails to pursue social objectives adcquate. This act was first proposed in 1999 but was postponed because of a lack of consensus, and, in revised form, was not passed into law until the end 2011. However, the revised Act failed to meet the demands of the social soulled ing movement (SHAC, 2011b). Only 10 per cent of the newly built so-called 'social housing' units are reserved for members of disadvalimenting social the Act relieves the government of responsibility fortherships with prihousing projects, relying rather on public and private partnination by banks vate developers. Several items regarding penalties for discritination the light of and landlords were deleted (SHAC, 2011b), this being critical in the light a 2012 survey by the Tsuei Ma Ma Foundation 
to lease their properties to single older people, those with low-incomes or disabilities, or single parent families (United News, 2012). In an attempt to boost Taiwan's childbirth rate, the act gives families with three or more young children preferential treatment in applying for a rental subsidy or social housing (Taipei Times, 2011). However, given the tiny number of units reserved for social rental housing, this policy could be viewed as an empty gesture.

In the most recent setback, legislators representing the interests of property developers have obstructed regulations regarding the registration of real transaction prices and information transparency, the eventual solution being to allow the government to announce only average housing prices in a block and prohibit taxation on real transaction prices. Without taxation based on real transaction prices, there is essentially little chance to rein in excessively high housing prices.

In February 2012, the KMT won a second presidential term and the newly designated Minister of Interior proposed a new housing policy to encourage young and poor people to move to the outskirts of the Taipei Metropolitan area by building new towns and improving public transportation. Critics accused the government of a policy of spatial discrimination (NOWnews, 2012), and suggested that the policy is intended to extend housing speculation to the suburbs. Campaign promises to help the disadvantaged seem to have fallen by the wayside, and the process of the social rental housing movement reveals the strong influence of private developers on the promarket state.

\section{Conclusion}

Taiwan's housing system has evolved through three stages from laissez-faire, through market regulation, to market promotion. The government has played a very limited role in the provision of affordable or low-income housing. At the end of the 1980 s, housing policy emphasized promoting homeownership and was highly reliant on market-based mechanisms, in particular through subsidizing mortgages. This approach was successful in increasing homeownership but also intensified the commoditization of housing. Today, the government lacks adequate mechanisms to counter speculation and control skyrocketing housing prices. Simultaneously high housing prices, high homeownership rates and high vacancy rates show that the current housing system is unable to distribute housing resources effectively.

The current housing system neglects people at the bottom of the economic ladder - those who cannot afford to own a home and even have difficulty in finding decent rental accommodation. A rapid process of economic restructuring has widened social inequality and expanded poverty, thus further intensifying housing problems. Since the 1980 s, neo-liberal trends in housing policy have resulted in further commoditization of housing, serving the interests of developers and investors at the expense of the disadvantaged.
Policies related to social welfare and social reproduction have positioned families as the major providers of social services. Women, increasingly working outside the home but still largely responsible for housework, are overwhelmed by their role in social reproduction. Consequently, as women have increased their economic status, they have delayed matriage and opted out of parenthood. Welfare and housing policies have also been very slow to tackle the problems of an ageing society, relying on market solutions and subsidies to help families, when they require them, to purchase social services. However, the profit motive inherent in private market services conflicts with the needs of low-income people, and the subsidies avallable for rent, childcare and elderly care are too small and not readily enough available to ensure the disadvantaged are treated well in the private market. A lack of regulations on rental housing, along with a lack of public social welfare facilities, also exacerbates the social pressure endured by individuals and families. More public assistance and intervention ate urgently needed.

Democratization in Taiwan Invites broader social participation, and disadvantaged people have formed advocacy groups to press the government to enact policy reforms. A new government agency, the Ministry ment of Health and Welfare, was forection of defamilization, with the public sector taking a larger role in social reprode-familization, with the pubse sesponsibility for care of children and the duction and familing continue to demand additional elderly. The social housing moverilly, this continued pressure will result in meaningful reforms in the future.

\section{References}

Central Bank of Taiwan (2011) Interest rates, new housing loans in five leading banks, Taiwan: Central Bank of Republic of China, http://www.cbc.gov.tw/ct.asp?xItem= 079 \& C Node $=528 \&$ mp $=1$ (accessed 1 November 2012 .

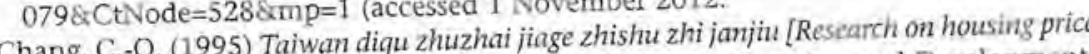
indexes in Taiwan area], Taiwan: Council for Economic Planning and Development. indexes in Taiwan area], Taiwan: Council for Economic Pan $(2010)$ Taibai shi fangia paomo hua zhi zai Chang, C.-O., Chen, M.-C. and Yang, C.-Y. (2010) Taibai shi fangjia paomo hra zm zai yen [Re-examine the housing bubble in Taipei], Taipei: Institute for Physical Planning and Information, http://www.realestate.com.tw/duckhouse/b

conference/bubble\%20news.pdf (accessed 1 November 2012).

Chang, J.-F. (2011) Laodong shehuei xue [Labour sociology], Taiwan: Chengchi University

Press.
Chen, Y.-L. (2011) New prospects for social rental housing in Taiwan: The role of housing affordability crises and the housing movement, International foumal of Housing Policy, 11(3), 325-38,

Chen $Y$. and W. Li W. (2011) Neo-liberalism, the developmental state and housing Chen, Y.-L. and W. Li, W. (20. Sark, A. Saito and R. Hill (eds) Locating Neoliberalism in policy in Taiwan, in: B,-G. Park, A. Saito and R. Ftates (Oxford: Wiley-Blackwell), East Asia: Neoliberalizing Spaces in Developmental States (Oxford: Wiley-Blackwell), pp. 196-224. 
China Times (2010a) Fonglia yi zai biaosheng yaoguai cuowu zhengce caocuo [Housing prices keep rising due to false policies], 7 March 2010, http//hk huaxia com/thping $\mathrm{mtlj} / 2010 / 03 / 1782892 . \mathrm{html}$ (accessed 1 November 2012).

China Times (2010b) Taiwan 18zen Jijin baiwon fuhao paihangbang shejia shangzheng kao fangdichan [Taiwanese rich people are among Forbes billionaires due to the boon in real estate market], 12 March 2010, http://www chinanews com/tw/tw boom news/2010/03-12/2165955.shtml (accessed 1 November 2012).

China Times (2011) Pingyi fongiia? Xuezhe: kemai duan won jia de [Lower housing prices? Scholars critique that the social housing can be resold and is not real social housing] 9 July 2011, http://news.chinatimes.com/focus/11050105/112011070900116ing, (accessed 9 July 2010).

Chu, W.-W. and Hung, C.-Y. (2002) Ziyoulnua yu qiye jituanhua de qushi [Business groups in Taiwan's post-liberalization economy], Taiwan: A Radical Quarterly in Social Studies, $47,33-83$.

cnYES.com (2012) Shehui zhuzhai chulong guo wu zhe fuxi la [The production of social housing will benefit the home buyers], 10 January 2012, http://house.cnyes. $\mathrm{com} / \mathrm{News} / \mathrm{tw}$ housenews/201201 t0153159422028012/C, http://house.cnyes. 10 January 2012)

Construction and Planning Agency (CPA) (2006) Zhonghua mingquo jiushi wu nia neizheng bu yingjian sha jikan xiaji hao [The lournal of the Ministry of the Interior, Summer 2006], Taiwan: Ministry of the Interior.

Construction and Planning Agency (CPA) (2007) The statistical yearbook of constriction and plarining agency, Taiwan: Ministry of the Interior, http://w3.cpami.gov.tw/ statisty/95/9S_htm/index.htm (accessed I November 2012)

Department of Household Registration, Ministry of Interior (2012) Zenkou ziliao ku [Demographic database], Taiwan: Ministry of the Interior), http://www.ris.gov.tw, 2h_TW/37 (accessed 1 November 2012).

Department of Statistics, Ministry of Interior (2008) Dishou ruhu shenghuo zhuanigkuang xingbie fexi [Gender analysis of low-income household survey], Taiwan: Ministry of the Interior, http://sowf.moi.gov.tw/stat/sex/genderstat9802.doc (accessed 1 November 2012),

Department of Statistics, Ministry of Interior (2011) 98 nian laozen diaocha jiekou [2009 survey on the elderly], Taiwan: Ministry of the Interior, http://www.moi.gov.tw/ stat/news_content.aspx?sn=5060 (accessed 1 November 2012).

Directorate-General Budget, Accounting and Statistics (DGBAS) (1980, 1990, 2000 2010) Population and Housing Census, Taiwan: Executive Yuan.

Directorate-General Budget, Accounting and Statistics (DGBAS) (2007). The General Report on Gender 2007, Taiwan: Executive Yuan.

Directorate-General Budget, Accounting and Statistics (DGBAS) (2011a) National statistics, Republic of China, Taiwan: Executive Yuan, http://eng.stat.gov.tw/pub$\mathrm{lic/data/dgbas03/bs2/yearbook} \mathrm{eng/Y093.pdf;} \mathrm{http://eng.stat.gov.tw/public/data/}$ dgbas03/bs2/yearbook eng/y022.pdf (accessed June 2011).

Directorate-General Budget, Accounting and Statistics (DGBAS) (2011b) Bricf Report on 2010 Census Survey, Taiwan: Executive Yuan, http://www.dgbas.gov.tw/ ct.asp? xitem $=30077 \&$ ct Node $=3272$ (accessed 1 November 2012).

Directorate-General Budget, Accounting and Statistics (DGBAS) (2011c) Images of Women, 2011, Taiwan: Executive Yuan, http://eng,stat.gov.tw/public/data/dgbas03/ bs2/gender/2011lmagesOfWomen.pdf (accessed 1 November 2012).

Directorate-General Budget, Accounting and Statistics (DGBAS) (2012) Important indicators based on manpower survey results, by year, Taiwan: Executive Yuan, http://www dgbas. gov.tw/ct.asp?xItem $=28980 \& \operatorname{ctNode}=3247$ (accessed 1 November 2012 )
Fu, L.-Y. (2010) Congxing beikuang dian kan Taiwan de kuojia fuli tizhi [The model of the state welfare: Analysis from a gender perspective], Taiwan: A Ratical Quarterly in Social Studies, 80, 207-36.

Hu, Y.-H. (1995) Santai tungtang /Three-generation families: Myth and trap], Taiwan: Chu Liu.

Housing Department of Taipei City Government (1987) Gouzhai shinian: Taibei shi [Housing in Taipei: 1976-1985], Taipei: Taipei City Government.

Hsiao, H.-H. M. and Liu, H.-J. (1993) Taiwan de tudi zhuzhai wenti yu wuzhu wuzhe yundong de xianzhi [Land-housing problems and the limits of the nonhomeowners movement in Taiwan], Hong Kong Journal of Social Science, 2, 1-38.

Hsu, J.-Y. (2011) State transformation and regional development in Taiwan: From developmentalist strategy to populist subsidy, Intermational Journal of Urban and Regional Research, 35(3), 600-19.

Institute for Physical Planning and Information (IPPI) (2004-2011) Housing Demand Survey, Taipei, Taiwan: Ministry of Interior, http://www.ippi.org.tw/ (accessed 1 November 2012).

Li, J.-H. (2010) Taiwan xingping Jieji de xingcheng yu yinying dueiche [The formation of new poor class and the soluttons], Xing shelutiei [New society for Taiwar], 10 , 16-20, available at http://www.taiwansig.tw/index.php?option=com_content\&task =view $\&$ id $=2730 \&$ Itemid $=123$ (accessed 1 November 2012 ).

Li, W. D. H. (1998) Housing in Taiwan: Agency and structure?, Singapore: Ashgate.

Liberty Times (2011) Pingfu chaju biao 75 bei zuizhao 5 per cent Jiating nian shoude 5.1 won [The incorne disparity increases to 75 Times. The annual income of the lowest 5 pet cent household is only NT\$51,000), I2 April 2012, hup://www.liberty times.com.tw/2011/new/apr/12/today-e1.htm (accessed 1 November 2012).

Liberty Times (2012) Bujin pingfu chaju liwei pi nianbei chaju ye e hua [The legislators criticize that not only the gap between the rich and poor but also the north and south have increased], 28 March 2012, http://www.libertytimes.com.tw/2012/ new/mar/28/today-fo3.htm (accessed 1 November 2012).

Lin, J.-H., Hung, J.-S., Li, J.-H., Wang, J.-C. and Chang, F.-Y. (2011) Beng Shi Dai [The Falling Generation: The Crises of Big Corporation, Poverty, and Low Fertitity Ratel, Taiwan: Taiwan Labour Front.

Mi, F.-K. (1988) Taiwan de gong gong zhuzhai zhengce [Public housing Policy in Taiwan], Taiwan: A Radical Quarterly in Social Studies, 1(2/3), 97-147.

NOWnews (2012) Li hong yuan zhuzhai zhengce lantu bianxiang jieji qishi [The new housing policy implies status discrimination], 25 February 2012, http:/6 www.nownews.com/2012/02/25/91-2789139.htmitixzz10oWyAY8z (accessed 1 November 2012).

Peng, 1. and Wong, J. (2010) East Asia, in: F. G. Castles, S. Leibfried, J. Lewis and C. Pierson (eds) The Oxford Handbook of the Welfare State, pp. 656-70, Oxford: Oxford University Press, avilable at http://japanfocus.org/data/OHWS_Kap45.pdf (accessed 1 November 2012).

Ramesh, M. (2003) Globalization and social security expansion in East Asia, In: L. Weiss (ed.) States in the Global Economy: Bring Domestic Institutions Back, pp. 83100, Cambridge: Cambridge University Press.

Social Housing Advocacy Consortium (SHAC) (2010) Taiwan shehui zhuzhai shuotie [The arguments for 'social rented housing' in Taiwan], 4 October 2010, http:// socialhousingtw.blogspot,com/2010/10/blog-post_04.html (accessed I November 2012).

Social Housing Advocacy Consortium (SHAC) (2011a) Zhummeng yihan juzhu bu chengyi zai taibei shi kongyin chuzu zhuzhai changyan [SHAC felt sorry about 
the social injustice in Taipei's public rental housingl, 7 November 2011, http://soc allousingtw.blogspot.com/2011/11/blog-post.html (accessed 1 November 2012). Social Housing Advocacy Consortium (SHAC) (2011b) Zi uo kanjue liang hou de
juzhu zhengyi (The 'housing justice' only makes the 13 December 2011, http://socialhousingtw html (accessed 1 Thei

Taipei Times (2011) Cabinet passes proposed bill on social housing, 23 September 2011, http://www.taipeitimes.com/News/taiwan/archives/2011/09/23/2003513987 (accessed 1 November 2012).

Tseng, S.-C. (1994) Zhanhou Taibei de dushi guocheng yu dushi yishi xing gou zhi yanjou [The study of urban process and urban consciousness in postwar Taipei]. Doctoral dis sertation, Taiwan: Graduate Institute of Building and Planning, National Taiwan University.

United News (2012) Dansheng laoren bao shou xishi [Single elderly were discriminated on renting houses], 29 February 2012, http://money.udn.com/house/sto rypage.jsp?t_ART_ID=258431 (accessed 1 November 2012).

Wong, J. (2004) Healthy democracies: Welfare politics in Taiwan ard South Korea, Ithaca, NY: Cornell University Press.

Wu, J.-M. (2010) Disan Zhungkuo Xiangxiang [The third imagiration on China], in: J-M. Wu, Y. Fan and E.-D. Ku (eds) Zhishu Bingeng niandai [The Age of Colourfit? Order: 1990-2010], pp. 353-83, Taipei: Left Bank.

Wu, S.-T. and Wu, S.-H. (2004) Goumai nengli touji yu da taibel digu zhi fongwu jlage Afrordability, speculation and housing prices in Taipei], Journal of Housing Studities, $13(2), 1-22$

Xie, W.-Y. (2010) Haizi sheilai zhaoku TWho is going to take care of the kids? The analysis of Taiwan's childcare policy], Taiwan: Child Welfare League Foundation, htip://www. children.org.tw/upload/File/researcher/3vision2-1-1.pdf (accessed 1 November 2012).

Xiong, I.X. (2012) Budang fangnu wuke quanou yeyou choutian [Not being a housing slave, the shell-less snail can also enjoy a spring time], Tianxia Magazine, 493, http://m.cw.com.tw/article/article.action?id $=50314468$ \&idSubChannel $=38$ (accessed
1 November 2012).

\section{Housing as a Social Welfare Issue in Thailand}

\author{
Yap Kioe Sheng
}

\section{Introduction}

Thalland has changed considerably over the last decades following rapid economic growth based on export-oriented industrial development, an expansion of the middle class and a decline in absolute poverty. However, economic activity is still largely concentrated in and around Bangkok and income inequality is high. The country is urbanizing through large-scale, but often circular, rural-urban migration, fife expectancy is increasing and fertility rates are below replacement level. Except for health care, social welfare programmes are rudimentary and cover mainly govemment officials and some formal-sector workers. Society expects individual efforts, supported by the family and the community, rather than social programmes of the government to ensure a basic quality of life for all.

The approach to housing bas been consistent with this expectation. Policies primarily aim at supporting private sector housing development to meet the demand of middle-income households. They include measures to open land for urban development through an expansion of infrastructure, and a flexible enforcement of zoning plans and building regulations. Many urban poor cannot afford formal private sector housing and have to rely on the informal private sector, which combines an unregulated market and varying degrees of self-help and community action. It delivers temporary housing and leaves many residents with a constant fear of eviction.

Most government housing programmes for the poor are limited in number, scope and impact, and they stay clear of the vested interests of landowners by not addressing the fundamental issue of access to urban land. The government's primary low-income housing programme (Baan Mankong) supports families and communities in buying or leasing land from public and private landowners and provides loans and grants for land purchase, infrastructure development and house construction or improvement. There is, however, no coherent and comprehensive package of measures that can be described as a pro-active national housing policy to ensure access to adequate lousing for all. 